\title{
Mirchond's
}

\section{Geschichte der Seldschuken}

ans dem Persischen zum ersten Mal tubersetzt and mit historischen, geographischen und literarischen

Anmerkungen erläutert

Yon

Dr. Johann August Vullers,

Professor der morgenländischen Sprachen und Literntur an der Univergitāt Giegsen.

Mit ciner Geschlechtstafel und einem Sachregister.

Giefsen 1837 .

Druck uad Verlag von G. F. Heyer, Vater. 

seiner Königlichen Hoheit

\section{Ludwig II.,}

Grofsherzoge von Hessen nnd bei Rhein

etc. etc. etc.

$$
\text { dem }
$$

grofsmüthigen Beförderer

$$
\text { der }
$$

orientalischen Literatur

in tiefater Ehrfurcht

grewidmet. 
